\title{
Maxillofacial Radiology 166
}

SADJ November 2018, Vol. 73 No. 10 p623

CJ Nortjé

The images below are of two male patients, who presented to the Department with the main complaint of tender soft tissue swellings of the mandible, developed over 12 months. Discuss the radiological features. What is your differential diagnosis?

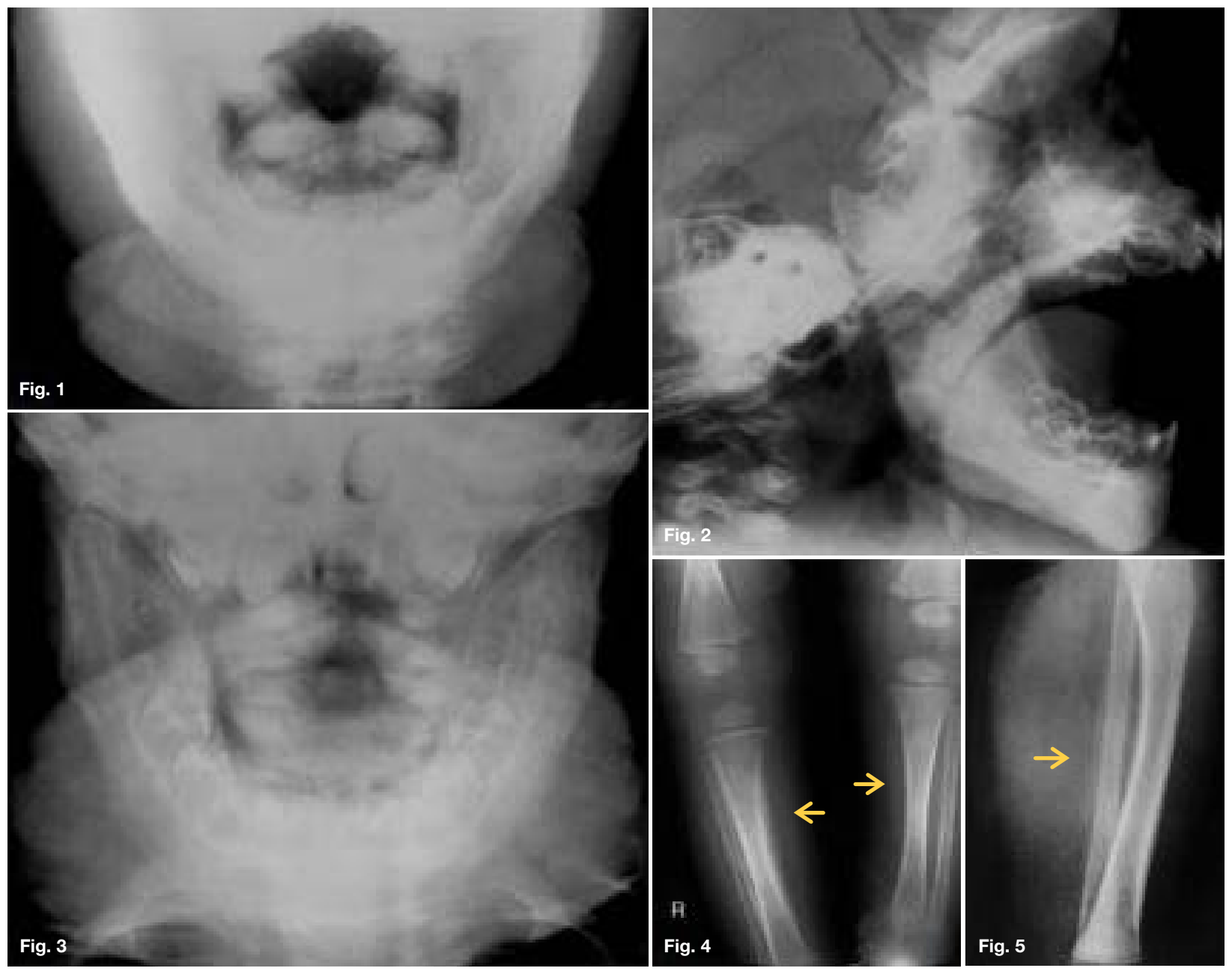

\section{INTERPRETATION}

Posterior-anterior view (Fig.1) showing soft tissue swelling and new periosteal bone formation in the anterior mandible. Lateral skull projection (Fig.2) showing cortical hyperostosis affecting both jaws. Another patient (Fig.3) showing hyperostosis of the mandible. Fig.4, same patient as Fig.1, showing cortical hyperostosis of long bones: note periosteal reaction with maintenance of original cortical outline deep to the lesion (yellow arrows). Fig.5 (same patient as Fig.3) showing cortical hyperostosis of the fibula. Diagnosed as Caffey's syndrome, an unusual cortical thickening occurring in the bones of infants (Infantile Cortical Hyperostosis, Caffey-Silverman's syndrome, or Smith's syndrome). Characterized by irritability, mild fever, soft tissue swelling and radiographic evidence of periosteal reaction, particularly of the mandible. The etiology is obscure, but infection may be responsible. In the vast majority of infant sufferers, onset is from two to four months of age, but it has been observed radiographically as early as five weeks prenatally and as

CJ Nortjé: BChD, PhD, ABOMR, DSc. Faculty of Dentistry, University of the Western Cape. E-mail: cnortje@uwc.ac.za late as seven years. Initially characterized by a tender, soft tissue swelling over the face, thorax or extremities; which often undergoes remission and exacerbation. The facial swelling is symmetric, located over the body and ramus of the mandible and is so striking that clinical diagnosis is made with considerable assurance. The most commonly affected bones are the mandible and ribs, less so the clavicle, tibia, ulna, femur, rib, humerus and fibula. There is slight periosteal thickening and a considerable increase in the width of bone due to subperiosteal new bone formation. The new bone undergoes resolution slowly and, although clinical improvement occurs within a few months, radiographic evidence may persist for years. Histologically, the pathologic process involves the overlying soft tissues as well as bone and periosteum.

\section{References}

1. Farman AG, Nortje CJ \& Wood RE: Oral and Maxillofacial Imaging. $1^{\text {st }}$ Ed. Mosby, St. Louis. Missouri, 1993 p 109-11.

2. Pindborg JJ \& EJ Hjorting-Hansen: Atlas of Diseases of the Jaws, W.B. Saunders, USA, 1974 p 200-1. 